AperTO - Archivio Istituzionale Open Access dell'Università di Torino

Simulacra and Sustainability Disclosure: Analysis of the Interpretative Models of Creating Shared Value

This is a pre print version of the following article:

Original Citation:

Availability:

This version is available http://hdl.handle.net/2318/1633525

since 2018-04-06T10:24:18Z

Published version:

DOI:10.1002/csr.1417

Terms of use:

Open Access

Anyone can freely access the full text of works made available as "Open Access". Works made available under a Creative Commons license can be used according to the terms and conditions of said license. Use of all other works requires consent of the right holder (author or publisher) if not exempted from copyright protection by the applicable law. 


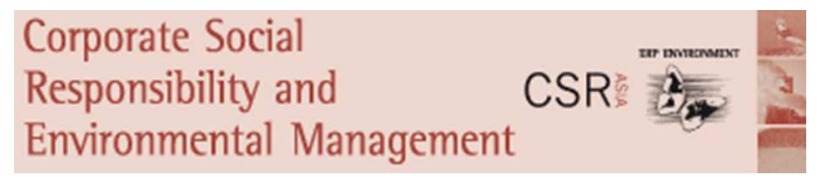

\section{Simulacra and sustainability disclosure: analysis of the interpretative models of Creating Shared Value.}

\begin{tabular}{|r|l|}
\hline Journal: & Corporate Social Responsibility and Environmental Management \\
\hline Manuscript ID & CSR-16-0150.R2 \\
\hline Wiley - Manuscript type: & Research Article \\
\hline Keywords: & $\begin{array}{l}\text { Creating Shared Value (CSV), Simulacra, Signalling theory, Interpretative } \\
\text { models, shared value, sustainability disclosure, CSR }\end{array}$ \\
\hline \multicolumn{2}{|l}{} \\
\hline
\end{tabular}

SCHOLARONE ${ }^{m}$

Manuscripts 


\title{
Simulacra and sustainability disclosure: Analysis of the interpretative models of Creating Shared Value.
}

\begin{abstract}
Business scandals, environmental disasters, and the growing attention to malnutrition and starvation around the world, are emphasizing the criticism toward capitalism and the way business is approached. CSR and sustainability theories are becoming understated as Porter \& Kramer's "Creation of Shared Value" (CSV) emerging concept has argued. Indeed, CSV is getting increasing attention from the corporate and professional world as well as gaining controversial judgments and reviews by CSR and sustainability scholars. Indeed, CSV appears more as a 'buzzword' rather than a theoretical concept. After outlining the underlying debate, our study critically examines how worldwide organisations have approached and interpreted CSV in their sustainability disclosure practices. In that sense, similarly to Plato and Baudrillard's concept of 'simulacrum', companies adopting CSV create an interpretation of their practical reality through definitions and images. Qualitative and rather innovative techniques are applied to analyse and categorize the narrative and graphical signals provided by a sample of leading organisations within their sustainability disclosure. Our findings show that, overall, CSV is not view as something unrelated to CSR, not just philanthropy, but a strategically oriented shift from sustainability which stresses the inclusion of stakeholders' needs. Given the current lack of research addressing how CSV has been interpreted and disclosed, our study provides a significant contribution to the current academic debate.
\end{abstract}

\section{Introduction}

Over the last two decades, an increasing number of corporations and businesses have become aware of ethical, social and environmental issues and, in general, the responsibility and sustainability of business. Indeed, these topics have driven a relevant amount of scholarly research as well as the development of several theories and approaches (Garriga and Melé, 2004; Gray, Owen and Adams, 2009). However, worldwide business scandals, environmental disasters and the growing attention to malnutrition and starvation, are emphasizing the criticism toward capitalism and the way business strategies are approached. Furthermore, the up-trending examples of shared and circular economy practices (such social innovation, social entrepreneurship, social ventures, hybrid companies, etc.), are dramatic calling to further account for the social nature of markets within ordinary business approaches (Murray et al, 2010, p. 141). Importantly, a new concept has emerged among organisations besides their own practices in the CSR and sustainability fields, namely the concept of Shared Value Creation (CSV).

If it's true that CSV has generated enthusiasm in the business and corporate community it has not been free of criticism, especially from the academia and other research communities. 
Despite the controversies, the idea of linking strategy, social and societal goals is appealing, even more if this can systematize previously underdeveloped disconnected areas of CSR/sustainability research and practice.

Indeed, a large number of organisations around the world have started to adopt and include within their external disclosure (i.e. sustainability reporting, integrated reporting, investor relations, corporate websites, press releases, etc.) CSV related terminology such as 'shared value', 'sharing value', 'creating shared value'. However, current CSV related practices and approaches are quite different. While some organisations have developed some specific CSV initiatives by investing high amount of resources, changing completely supply chains and processes, other organisations don't provide relevant insights and just refer to CSV in their communications to stakeholders. As argued by Dembek et al. ( 2015) so far, 'shared value' appears to be more of a buzzword than a theoretical concept.

Although CSR and sustainability theory and practice have been broadly studied and investigated (Aguinis and Glavas, 2012; Carroll, 1999; Kitzmueller and Shimshack, 2012; Lee, 2005, Lindgreen and Swaen, 2010; Lockett et al, 2006, Schmitz and Schrader, 2015), there is still little academic research focusing on how organisations are approaching and interpreting to CSV within their sustainability practices. Therefore, our study aims at filling this gap by critically examining the meaning of several CSV related disclosure practices from a cognitive and ontological perspective. Specifically, we focus on the disclosure provided by a sample of worldwide organisations. By applying signalling theory (Connelly et al, 2011; Spence, 2002), we identify relevant patterns related to CSV disclosure to understand how this concept has been interpreted and approached. Indeed, the interpretation of the reality given by the organisations' reported signals, can refer to the relationship between reality and simulacrum discussed by Plato in the Myth of the Cavern (514 a-518 b) and addressed by Baudrillard (1968; 1994), herein viewed in the field of accountability and disclosure practices. The application of simulacra effects in accounting and reporting has been already studied in the work of Macintosh et al.(2000) and Mattessich (2000). Consistently, Quattrone (2009) discussed the role of visualisation in accounting and reporting, concluding that accounting scholars have not devoted enough attention to Accounting information as provider of pictures and images, because they tend to focus more on numbers and text.

Our findings show that, overall, CSV is not view as something unrelated to CSR, not just philanthropy, but a shift from a strategic view of "sustainability" towards an inclusive stakeholders oriented model of value creation.

\section{Literature review}

\section{CSV and CSR strategies}

Shared Value is a managerial concept first appeared in a 2006 Harvard Business Review article written by Michael Porter and Mark Kramer entitled "The link between competitive advantage and corporate social responsibility", that discusses the missing link between CSR practices and the strategies underlying competitive 
advantage (Porter and Kramer, 2006). Specifically, Porter and Kramer (2006), identify four prevailing CSR and sustainability areas which fail to miss the link with strategy: (i) the moral appeal which is found in "doing the right thing"; (ii) the principle of sustainability invoking economic, social and environmental performance (Elkington, 1997); (iii) the license-to-operate dealing with social issues and reputation by satisfying external audiences (Werther and Chandler, 2005); (iv) and the need for engaging with stakeholders (Freeman, 1984). Five years later, building on their field experience, they define the concept of Creation of Shared Value (CSV) as: "policies and operating practices that enhance the competitiveness of a company while simultaneously advancing the economic and social conditions in the communities in which it operates" (Porter and Kramer, 2011p. 4). CSV is conceptualized as a strategic approach that focuses on identifying and expanding the connections between societal and economic progress by addressing social issues that interconnect with the business. Such strategies shall include specific societal needs in their value propositions consistently with Porter's previous studies on competitive advantage (1979; 1980; 1985). Therefore, CSV strategies call for long-term investments driving sustainable competitiveness by consistently addressing social and environmental goals. For instance, such strategies may include reconceiving products and markets, redefining productivity in the value chain, and enhancing local cluster development (Porter et al., 2012p. 3).

Despite their arguments, Porter and Kramer have not been the first to link CSR and competitive advantage, as an increasing amount of previous studies have already addressed the strategic implications of CSR and sustainability practices (Burke and Logsdon, 1996; Engert et al, 2016; Freeman, 1984; Jensen, 2002).

Although focusing exclusively on environmental corporate issues, Hart (1995) had asserted that CSR can lead to sustainable competitive advantage, and this is further increased if these are supported by governmental and industry policies (McWilliams, et al. 2002). Accordingly, Jenkins (2004) had pointed out that organizations need to better understand the complex nature of the communities in which they operate in order to develop suitably tailored sustainability strategies. However, organizations have often failed to seek, understand and integrate community perceptions into CSR policies and practices (Idemudia and Ite, 2006). More recently, other studies have addressed the relationships between CSR and sustainability practices with strategy by demonstrating their fundamental role in shaping the direction of a business from top to bottom (Baumgartner, 2014; Kolodinsky and Bierly, 2013), and their strong link within value creation (Harrison and Wicks, 2013; Juscius and Jonikas, 2013). Accordingly, scholarly evidence has showed that sustainability and CSR practices have a positive influence in creating corporate value if the focus is on financial and market performance (Boesso et al., 2015; Marti et al., 2015; Michelon et al., 2013; Pätäri et al., 2014; Patari et al., 2012).

Bringing CSR and sustainability in the control room, means incorporating social characteristics or features into products and manufacturing processes, adopting " $\mathrm{g}$ local" supply chains, adopting progressive human resource management practices, achieving higher levels of environmental performance through recycling and pollution 
reduction, and advancing the goals of community and society (Babiak and Trendafilova, 2011; Klein and Dawar, 2004; Lund-Thomsen and Nadvi, 2010). Research seems to overlook that strategies are made in a contingency way, and assumes instead that sustainability strategies are made in a purely planned way (Neugebauer et al., 2016). Therefore, organizations still need to adopt an holistic perspective to better catalyze sustainability drivers for strategic change: internally by shaping leadership and their business case, externally by focusing on reputation, customer demands and expectations, as well as regulation and legislation (Duran and Bajo, 2014; Lozano, 2015; McWilliams et al., 2016). As a matter of fact, in a recent HBR article, Kramer and Pfitzer (2016) provide several real examples, stress about the importance of building a "Shared Value Ecosystem", meaning that to advance shared value efforts, businesses must foster and participate in multisector coalitions.

\section{$C S V$-related debate}

Accordingly, CSV has been subject of great debate and review. On the one hand some scholars are considering it a powerful evolution of CSR (Bosch-Badia et al., 2013; Moon et al., 2011), but on the other hand CSV has been object of strong criticism both as a business idea (Denning, 2011) and as a theoretical concept (Aakhus and Bzdak, 2012). For instance, one of the first critics (Economist, 2011), discussed the shallowness of the CSV concept, importantly, when it generalizes describing how private organisations have always failed to do whatever effect at a social level. Consistently, Beschorner (2013) highlights how CSV misses to radically innovate from what has been already developed in management sciences, and specifically in the area of strategic CSR. Furthermore, Crane et al. (2014) argue that CSV looks naïve by ignoring the tensions that could exist between social and economic goals, it is unoriginal as it simplifies the role of corporations in society and ignores the challenges arising from business compliance. The argumentation is that there are alternative ways to re-invent capitalism and CSV is just one of the many viable means and innovation which can be used to reconstruct a sustainable corporate worldview (Crane et al., 2014; Denning, 2011; Denning, 2012; Hartman and Werhane, 2013). Moreover, Crane et al. (2014) argue about the holistic framework proposed by the CSV model, where conscious capitalism, social entrepreneurship, social innovation and bottom of the pyramid business model are grouped under a unique concept.

Indeed, John Elkington, the father of the triple bottom line approach (1994; 1997) argued that despite CSV has many virtues, is unlikely to pick up some of the really thorny CSR issues, such as human rights or bribery and corruption, and therefore it would be better to don't abandon what has been developed so far in the CSR and sustainability fields (Elkington, 2011). Consistently, Maltz et al. (2011) present CSR as a vehicle for a wide array of scholars, critics and activists to condemn what they perceive as excessive self-concern by business elites and to encourage firms to bring more attention and resources to address issues by creating 'value' across a range of topics such as the environment, job security, education, regulation, corporate governance, etc. Moreover, Szmigin and Rutherford (2013) propose to adopt Adam Smith's Impartial Spectator approach (Smith, 1759p. 10) in order to build the trust 
link that underpins shared value between business and its consumers and create a virtuous sustainable cycle. On the contrary, Wilburn and Wilburn (2014) rehabilitate CSR by arguing that CSV, in its original form, fails to address the 'responsibility' underlying a business, since the only reason for addressing societal needs is the increasing of profits.

Despite such argumentations, several organisations at a worldwide level have started to include CSV-related terminology within their corporate communication, however there is a lack of systematic research mapping how the corporate world is institutionalizing and interpreting this "Big idea" (Dembek et al., 2015). Therefore, the aim of our study is to conceptualize and scrutinize the evolution of the topic and its ontological meaning, by focusing on the analysis of CSV-related disclosure.

\section{Hypotheses development}

Despite Porter and Kramer's argumentations have made CSV look something that cannot satisfy an academic (Rocchi and Ferrero, 2014), scholars agree with the core view of CSV, and the great amount of debate led CSV to achieve popularity among professionals and practitioners. For instance, Porter \& Kramer's 2011 article has been widely cited on Google Scholar (approximately 3,200 times) and "CSV" is one of the most quoted business concept on the web. An increasing numbers of corporations started adopting CSV within their corporate strategies leading to specific actions, communication and disclosure (Biswas et al., 2014; Bockstette and Stamp, 2011; Gonçalves, 2014; Larsson et al., 2013; Panapanaan et al., 2016; Pavlovich and Corner, 2014; Rocchi and Ferrero, 2014; Schmitt, 2014; Spitzeck and Chapman, 2012). Consistently, advisors and consultants changed their sustainability and CSR offering by including CSV-related planning, measurement, reporting and other practices. Moreover, the major reporting bodies that issues guidelines for social and environmental accountability (i.e. IIRC, UN Global compact, ISO 26000 and OECD Guidelines for MNE) are adopting some CSV concepts, such as "integration", "inclusion", and "materiality".

These trends invite attention and scrutiny from an academic perspective. As such, given the broad adoption that CSV is having in the corporate world, our study aims at contributing to the current debate by providing relevant insights and discussion on how major organisations are interpreting and approaching CSV from an ontological and cognitive perspective. The application of an ontological approach is important in order to test if a solid foundation is lagging behind CSV. In our study, ontology is considered as "the general theory of the types of entities and relations that make up their respective domains of interests, to provide a solid foundation for their work" (IAOA, 2015) . As such, we provide significant insights on the contents, and related formats and languages used to represent the reality behind CSV.

Reductio ad absurdum, if we consider CSV as a brand new reality (despite the current debate), our study could determine the existence of a new concept, the nature and the structure of a domain of interest that should be "brand new" and calls for a need of definition and design of specific accountability and disclosure practices. In this sense, 
we suppose that organisations applying CSV as "something new" will adopt new models and techniques to tell their stories. These stories will depict a "new reality", because CSV by definition, is something "brand new", completely different from CSR and other related concepts. Consequently, we suppose that the behaviour of organisations that started disclosing their CSV practices is similar to the one described by Plato's Myth of the Cavern. Specifically, men living in a cavern look at the shadows reflected on the walls perceiving these shadows as the reality, even if they are just the projections of simulacra (such as objects and statues). We suppose that organisations disclosing not the actual reality and neither its copy, but the simulacra of what they perceived as real, will end up generating a simulacrum effect. Macintosh et al. (2000) and Mattesich (2000) have discussed the Baudrillard's concept of simulacrum in accountability and reporting, as a sign, image, model, pretence, or shadowy likeness of something else. They conclude that many accounting and reporting signs are no longer referred to real objects and events; therefore, accounting and reporting no longer work according to the logic of transparent representation, stewardship or information economics. Their studies address the relevance of the application of such philosophical theories within accountability and reporting research, because the concept of accounting and disclosure itself should be seen as a way to shape and create the reality in which companies operate (Coy and Pratt, 1998). In that sense, we assume that the information included in sustainability disclosure reflects the organisations' interpretation and adaptation of CSV in their own context, and therefore is able to provide ontological meaning.

In other words, by analysing the cognitive content of sustainability disclosure it is possible to derive the organisations' interpretation of CSV as a concept with a specific meaning. We cannot assume that such CSV descriptions are the reality of facts - as we are not illustrating case studies or participatory active research - but we can assume that definitions and graphical representations are acting as simulacra. In order to complete a logic consequence, according to Porter and Kramer (2011 p. 4), we postulate that: "Shared value is not social responsibility, philanthropy, or even sustainability, but a new way to achieve economic success". Accordingly, we expect that CSV practices and related disclosure will show the interpretation of this "Big idea" through new knowledge, paradigms, and concepts. However, if the analysis will show any kind of cause-effect relationships between or within former CSR-related concepts, we cannot admit the originality of CSV. Therefore, our hypotheses are:

H1: CSV cannot be explained throughout cause-effect relationships within existent paradigms of CSR,

H2: Organizations adopting CSV are not creating a new reality, but only interpreting CSR-related concepts in a new way.

The originality of CSV will be demonstrated creating new knowledge, and in ontological terms, by explaining the use of such new concepts. The use of new links between existent concepts will confirm the holistic view of CSV as an "umbrella 
label" confirming the arguments by Crane et al. (2014). As such, while the aim of H1 is ontological in the sense of providing definitions, $\mathrm{H} 2$ is cognitive in explaining and interpreting CSV accountability within the organisations' sustainability disclosure.

\section{Research design and Methodology}

\section{Sample selection}

Our evidence is based on the disclosure provided by a sample of international organisations, that approached CSV practices in the period 2011-2015. We started by selecting the list of organisations labelled as CSV "pioneers" by Bockstette and Stamp (2011), and then added the organisations who joined the Shared Value Initiative (SVI) in the following years. In addition, we included also those organisations that registered they reports on the Global Reporting Initiative (GRI) and/or the International Integrated Reporting Council (IIRC) databases. These two databases were browsed looking for the last available reports containing explicit references to "shared value" or "sharing value". We added one not-for-profit organisation, Farmhub, because their website publishes an infographic which is useful for our study. Accordingly, our final sample is composed by 29 worldwide organisations imposing an affordable limit to guarantee the application of our methodology (Table 1). Furthermore, for each organisation, we have gone backwards (since 2011, published definition of CSV) collecting 87 reports with explicit reference to $\mathrm{CSV}$.

For the collection of visual representation, different typologies of CSV-related disclosure have been considered (i.e. images on corporate websites, press releases, and sustainability reports). Because the data has been almost qualitative, we applied analytical techniques in order to outline and map the different underlying ontological approaches. Figure 1 provides an outline of the sample selection process and the resulting data, while Table 1 provides a list of the organisations included in our sample broken down by industry, size and location.

\section{[INSERT FIGURE 1 HERE]}

Figure 1 Outline of the sample selection process and related outcomes

\section{[INSERT TABLE 1 HERE]}

\section{Methodological approach}

In order to analyse the structure of the collected CSV-related disclosure, and understand how organisations are behaving, we applied the theory of signals (Spence, 
2002). According to this theory, the aim of sustainability disclosure is to provide social and environmental signals to stakeholders. Consequently, stakeholders can assume that the organisation is well run and relatively free from unexpected social or environmental (de-legitimating) shocks and issues (Gray et al., 2009). This represents an interesting update to the theory of information usefulness, which simply suggests that information will be produced if appropriate decision-makers find it useful to their decisions. However, CSR-related information has been found to be relevant only for a limited number of users and "ethical investors" (Chan and Milne 1999; Epstein and Freedman 1994; Firth 1979; Milne and Chan 1999; Neu et al. 1998) because information usefulness disregard the receiver of the information (i.e. investors, employees, local governments, citizens, etc.). The theory of signals is designed to solve these issues, especially in information asymmetry contexts, by accounting for the features of the whole information process composed by 'sender $>$ signal $>$ recipient' (Connelly et al., 2011). Accordingly, our study collected information about: senders (profit orientation, business sector, country and geographical markets) and signals (channel, frequency, formal representation; quotation). Because the collected signals where namely narrative (i.e. text) and visual (i.e. images, graphs), we applied qualitative content analysis and information visualization, as discussed in the following paragraphs.

\section{Analysis of textual signals}

We applied qualitative content analysis to collect the CSV-related signals within the sustainability disclosure (Weber, 1990). CSR scholars have broadly adopted this methodology to interpret corporate voluntary disclosure provided in sustainability reports (Unerman, 2000). Moreover, in order to understand the meaning and the relationships within the collected data, we adopted cognitive fuzzy mapping. Fuzzy cognitive maps are graph structures used to represent causal reasoning, their fuzziness allows distinct degrees of causality between hazy causal concepts (Kosko, 1986). We used Mental_Modeler, a software widely adopted in social science studies (Gray et al., 2013), as well as stakeholder oriented studies (2012). Given the nature of our study, we had to apply a simplified version of the model, identifying only cause-effect relationships and opposite-contradictory relationships as inspired by Norese and Salassa (2014).

\section{Analysis of visual signals}

We applied information data visualization to understand the meaning of corporate diagrams, charts and graphs, when these have been disclosed to explain the organisations' CSV approach. Information visualization is the study of visual representations of abstract data used to reinforce human cognition (Ware, 2013). It focuses on the creation of approaches for conveying abstract information in intuitive ways: in our case, the purpose is to understand if the corporate designs can be linked to specific cognitive meanings of CSV. Accordingly, the geometrical forms provided by organisations within their disclosure have been clustered and analysed. The 
adoption of this methodology in the field of sustainability, CSR and accountability, can be considered pioneering and experimental.

\section{Findings and discussion}

Our final sample includes 29 organisations, with 87 total reports collected and analysed. The sample is composed by a majority of multinational corporations (MNCs), which account for the $78.5 \%$ of the total sample and one social enterprise (FarmHub). If we look at the collected reports and the structure of the sample, it is clear that the concept of CSV has an international spotlight, reflecting dynamics and economic systems that are geographically distinct, different from cultural, social and economic perspectives.

These organisations provide textual, graphical and combined interpretative models. When the sole graphical models were not sufficient to understand the underlying interpretation of CSV, further analysis over time and other documents have been performed (i.e. press releases). This justifies the use of 87 documents as "channels", with a majority of sustainability reports [SR 80\%], Shared Value reports [SVR 3\%], annual report [AR, 17\%]. The collocation of the signal in the channel identifies the section of the report where the description (type: textual or visual) has been found. When the visual/graphical representation was sufficient to understand the organisation's meaning of CSV, the text has not been considered. However, that happened only in two cases: Nestlè (for the intensive use of the world 'shared value' along all the pages) and FarmHub (because they provide an infographic that already include many textual data). The specific description and structure of the signals is presented in Table 2, where the last column presents examples of the extracted CSVrelated disclosure.

\section{[INSERT TABLE 2 HERE]}

\section{Analysis of textual signals with cognitive maps}

The textual analysis has been performed by designing fuzzy cognitive maps with Mental Modeler software (Gray et al., 2013). The focus of the map has been on those sentences that can clarify the organisation's interpretation and view of CSV. In total, we analysed approximately 6200 words and 520 sentences. Cause-effect approach in cognitive mapping means the logic consequence between two words: $A \rightarrow B, B \rightarrow C$, then $A \rightarrow C$. In the case of multiple implications, such items reinforce the influence between the constructs, and are mapped with a marked arrow; when the logic consequence is negative, or it reflects an opposition, the arrow is orange and tagged with the minus sign (-), rather than the ordinary blue one with the plus sign (+). For instance, organisations stating that "CSV is more than sustainability», reflect their perspective of separate concepts, while declaring "CSV is related to develop clusters and projects to stakeholders», reflects the presence of positive relationships between 
concept such as CSV, development, projects and stakeholders. The resulting total cognitive map is presented in Figure 2.

Besides, a cluster of the information grouped by topics is provided in Figure 3 which depicts a global cognitive map, such map groups different CSV's perspectives including:

- Business-related terms such as corporate assets, business strategy, business eco-system and value creation (red cluster).

- Societal and environmental-related terms such as societal development, communities, citizenships, environmental care, eco-innovation (green cluster).

- CSR, sustainability, and triple bottom-line related terms such as sustainable development strategies, CSR initiatives, CSR strategies, etc. (yellow cluster).

- Stakeholders management related terms such as stakeholders engagement, stakeholder dialogue, suppliers, customers, partners, etc. (light brown cluster).

- CSV core and distinct features such as new level, shift, management concepts, think, way of being, etc. (black cluster).

\author{
[INSERT FIGURE 2 HERE] \\ Figure 2 Global Cognitive Maps on CSV
}

[INSERT FIGURE 3 HERE]

Figure 3 Clustered Cognitive Map

This finding confirms that CSV is not viewed as a unique concept, because it is always linked to other sustainability approaches which include references to the triple bottom line (Elkington, 1997), stakeholder management theory (Freeman et al., 2004) and instrumental stakeholder theory (Donaldson and Preston, 1995). Because structural semantic could help to determine the linguistic relations between the meaning of different words (Lyons, 1968), it is possible to select the influences "from" and "to" the block "Shared Value", as outlined in the maps presented in Figure 4 and Figure 5. Specifically, the comparison of Figure 4 and Figure 5 shows the "hyperonymy" of CSV, a semantic categorization meaning that CSV has a semantic field broader than the others it includes. For instance, as expressed by Figure 4, CSV has influences on managerial terms such as "programmes, policies, approaches, vision, strategy"; performance terms such as "perpetuity, growth (economic, business, sustainable), opportunities, competitive advantages, innovations, business interests"; sociological terms such as "communities, involvement, local community development, co-creations, societal values and needs". Conversely, CSV is view as "antonym" (two contrary lexemes) of sustainability-related terms such as "responsibility, philanthropy, social and environmental challenges, third element and shift". 
[INSERT FIGURE 4 HERE]

Figure 4 Influence from CSV

Specifically, if we focus at Figure 5, namely the influences of other concepts on CSV, the relationships with "CSR" are unclear. In fact, CSR activities and CSR initiatives are view as "meronym" of CSV, a semantic concept meaning "part of". For instance, while it is clear that shared value is not "philanthropy", and not just "sustainability" as highlighted by the marked orange arrow in Figure 4, the relationship with CSRrelated concepts is fuzzy. Some of them refers to CSV as a step over CSR, others refer to its inclusion/coexistence/addition to CSR. However, the cognitive map Figure 4 is not able to provide the degree of difference with CSR.

Furthremore, Figure 5 shows that CSV is interpreted as a business concept linked to terms such as "business, company, corporate assets, strategic business interests, core business, management concepts". Even though, it is also linked to terms such as "development, collaboration, and stakeholders". Indeed, looking at Figure 4 and Figure 5, it is clear that organisations defining shared value need to explicitly refer to existent concepts.

\section{[INSERT FIGURE 5 HERE]}

Figure 5 Influence on CSV

Semantic studies could also representing a useful tool in order to overcome the problem of cause-effect relationship, providing detailing description of opposition, addition, inclusion, coexistence between two terms. In our study we have focused our attention to the cause-effect relationship, while other influences have not been deeply detailed. For instance, Figure 6.a shows an examples of non-cause effect relationships where an organisation describes CSV to be more than business strategy (-), that is a way of being (-). On the contrary, another one (Figure 6.b) defines CSV as more than philanthropy, community involvement and sustainability stressing the holonymy between CSV and its related declinations (economic and societal values).

\section{[INSERT FIGURE 6 HERE]}

Figure 6 Examples of non-cause-effect relationship

Remarkably, the relationship between CSV and stakeholders-related terms is close and essential; even if the majority of organisations declared to create shared value "for" them, only a few declared to co-create shared value or distribute shared value "to" them. The relationship between CSV and stakeholders is outlined in Figure 7 
where CSV means essentially to "create projects for stakeholders, dialogue with, partnerships, trust, credibility, benefit, opportunities, and goodwill to stakeholders".

\author{
[INSERT FIGURE 7 HERE] \\ Figure 7 Relation between CSV and stakeholders
}

If we focus again at the different influences, there are some cross-relationships due to the fact that the interpretation of CSV is not unique and it's changing over time, and between organisations. For instance, every organisation has outlined a sort of CSV path during their different reporting periods. The first year of adoption of a CSVrelated mindset, disclosure is characterized by few citations, then in the second and third year, the citations increased in numbers (Table 3). The normalized data have been reported only for those organisations that have clear textual signals, repeated over time for at least two times.

\title{
[INSERT TABLE 3 HERE]
}

With the purpose of providing the reader some CSV highlights, organisations usually tend to increase the complexity of their inner definition year by year. After the first year of introduction, organisations tend to increase or decrease the focus of their report with a deep discussion of the dynamics and mechanisms of CSV. The reduction or the growth of complexity can be illustrated by focusing on a specific case where the cognitive map has changed notably over time for the same organisation, as outlined by Figure 8. Importantly, during the first year, CSV has been related to actions and programmes carried out for territorial development involving local suppliers. During second year, the definition increases its complexity becoming a concept that implies collaborations in projects with stakeholders to develop such collaborations, social investments and involvements. Finally, during the third year, CSV is defined as a very streamlined business vision bringing together community, participation and dialogue, and of course joining Shared Value Initiative.

\section{[INSERT FIGURE 8 HERE]}

Figure 8 Trend in complexity and its reduction over time (example of a single organization)

\section{Analysis of CSV visual representation}

If we focus on the visual results of our analysis, we found that the use of images, pictures, diagrams, and other graphical forms, is intended to be unintentionally linked to a precise scope. Perceptions are clearly attractive from the perspective of visualization, given that the goal of most visualization practices is supporting decision-making. For instance, Ware (2013 p. 224) states that "in entity-relationship modelling, entities can be objects and parts of objects, or more abstract things such as parts of organisations". Therefore, relationships are the various kinds of 
connections that can exist between entities. For example, an entity representing a wheel will have a part-of relationship to an entity representing a car. Usually, both entities and relationships may have attributes, and the attribute of an entity as complex as an organisation might be something unique. Attributes are often provided in the form of text labels attached to the boxes and lines, although occasionally dashed lines and other variations are used to denote their typologies. In our analysis, attributes are the organisations' narratives on CSV, which we have analysed with cognitive maps. The visual metaphors embedded in the narrative, like words such as connection, linkage, attachment, or part-of, suggest ways of graphical encoding relationships between entities. According to Ware (2013), such metaphors are not embellishments to language, but reflect the basic structure of thought. We assumed that the organisations publishing CSV diagrams and charts aimed at communicating unintentional messages, with different visual forms. Indeed, there are standard diagrams for use in entity-relationship modelling, but we were more interested in the different ways diagrams can be designed to represent entities, relationships, and attributes in an easily perceived manner. The signals collected have been clustered using the grammar of information visualization (Ware, 2013) in order to establish the relationship between the CSV-related concepts; the analysis is presented in Table 4.

According to Ware's visual grammar interpretation (2013 p. 225), the visual representations of CSV adopting the Eulero-Venn sets, (e.g. the ones included in the first row of Table 4), are aimed at narrating the links between different concepts (when shapes are merged), enclosed relations (when shapes are included into a bigger one), or partially enclosed (when shapes are located across a boundary). On the contrary, the case of asymmetrical relationships, organisations tend to represent their CSV approach with the use of a triangle, which recall hierarchy and prioritization. For instance, in the second row of Table 4, "compliance" is located at the bottom of the pyramid while CSV is at the top. Furthermore, sketches and storytelling are essential in order to narrate CSV mechanisms, while shapes linked together with the use of linking lines, sequences, linear relations, mean a "circular" representation of concepts; where circularity is a synonym of continuous growth and virtuous cycle. Moreover, the adoption of shapes which are enclosed in bigger ones or shapes that clearly fit between components, show that CSV is composed by different non-separate parts. For such organisations the interpretation of CSV has no meaning without the inclusion of concepts such as charity, compliance, or strategic CSR. The last row of Table 4 outline organisations representing symmetrical relations and bilateral links. These organisations visualize their stakeholder relationships by stating that the creation of shared value happens "among” stakeholders.

Indeed, such a categorization needs to be seen as experimental and additional to cognitive mapping analysis.

[INSERT TABLE 4 HERE]

Hypotheses' rejection and confirmation 
Narrative definitions analysed through cognitive maps show close and inter-functional links between CSV and CSR-related concepts (bilateral cause-effect relationships). Specifically, our cognitive maps showed CSV as a concept including/adding or coexisting with CSR, an upgrade of CSR, or locating the definition of CSV within CSR and stakeholder sections of their report. Additionally, this is confirmed by visual representation, where CSV is represented as multi-stakeholder approach or it is included in hierarchical representation based on sustainability. Moreover, we can affirm that the presence of multiple definitions of CSV inside the sustainability reports suggests the need for organizations to be clear and transparent in communicating a sustainability shift, which should happen primarily in their strategy. Even though, some organizations have joined the shared value "trend" and used CSV just as a buzzword (confirmed by the increased number of citation during the periods analyzed).

Therefore, $\mathrm{H} 1$ is rejected revealing that reporting for CSV practices is presented with cause-effect relationships with CSR-related concepts and existing paradigms, colliding with Porter and Kramer's postulate of "CSV is not CSR". Consequently, H2 is accepted because organizations' CSV-related disclosure is not creating a new reality, but only interpreting CSR-related concepts in a new way. In that sense, the new way invoked in the definition of CSV, is more addressed to a managerial mindset of approaching business for society rather than a real shift to something completely different.

\section{Conclusions and implications}

The main goal of our study is to provide relevant insights of the different approaches related to CSV from an ontological and cognitive perspective. In other words, the purpose of our analysis is to interpret and understand how organisations deal with CSV practices, if any, using related reporting practices as simulacra. Sustainability accounting, reporting and accountability can be viewed as simulacrum of the reality, therefore, we act like the men in Plato's Cavern, looking for pictures and deriving conclusion about the external real world which somehow is different from the way is perceived. As such, we adopt a signalling theory perspective to analyse a sample of organisations' CSV-related disclosure and apply information visualization grammar to interpret such representations of CSV. Indeed, Some organisations, seduced by CSV because of Porter's "label", repeat faithfully the lesson learnt; while others, adopt a continuous learning by doing organizational process, distinguishing and improving their inner meaning and interpretation of what is CSV and what is not. CSV appears to be strictly linked to CSR in cause-effect relationships, because the CSV-related disclosure demonstrates how CSV is substantially linked to existent concepts and theories.

The substantial lack of new knowledge and ontology let us conclude that CSV reporting is a simulacrum of a reality based on CSR, stakeholder theory, sustainability, philanthropy, collaboration with NGOs, social entrepreneurship, where 
CSV is an "umbrella" concept. Our work is coherent with Crane et al. (2014), stressing the importance of "sharing value" and adopting elevated societal issues as strategic priorities, herein demonstrated by the presence of words in our maps like "strategy", "strategic business interests", "opportunities", and "assets". Conversely, we note a discreet fuzziness in categorizing organizations' definitions of CSV in their reports, probably because the concept of CSV cannot be separated from CSR ans sustainability generally accepted terminology.

Furthermore our analysis demonstrate that the CSV concept is still evolving, and such heterogeneous approaches reflect different perspectives and strategies. In fact, the debate around CSV is nowadays focused on the continuum, from rebuilding legitimacy to CSR or to sustain the success of CSV "A class" cases (Crane et al. 2014; de los Reyes, Scholz, and Smith 2016) beyond critics. We support the idea of de los Reyes et al. (2016) of the need of telling the story of unsuccessful cases of CSV (B-type), and cases of CSV ineffectiveness in social impact creation and/or in budgeting implications. B-cases should enrich the managerial implication of adopting a CSV mindset and managerial skills needed to target successfully business results, and social outcomes as well. The use of sustainability accounting and reporting as simulacrum of the reality depicts a context where businesses adopting CSV need to change their core strategies to create value in social, environmental, and moral terms. Negative externalities can be reduced by developing an integrated approach, driven by ethical and sustainability principles, which lead to risk mitigations and defence of the organisation's reputational capital; in the meantime, positive externalities will increase by blending, stakeholders' needs, societal development, and business competitiveness. As such, managerial implications of a CSV mindset require distinctive capabilities of stakeholders' dialogue, needed to cover the naturally intrinsic gap between strategic governance of multinational corporations and geographically-wide grounded social impacts. Moreover, CSV could benefit of its historical roots on business strategy studies, giving companies managerial tools to bring together business objectives and societal goals. CSV could give suggestions on how reinterpret business strategies, on how make a sort of inclusive business process re-engineering and, most important, to define the differences between CSV and corporate dimensions (small businesses vs. large corporations) and corporate experience in tackling social issues (start-ups vs experienced entrepreneurial activities). In fact, as stated by Spence (2014), large firms routinely and systematically overshadow any other type of organization in the management and business literature. In CSV, this is outmost true, as the literature reports mostly cases of large corporations, while small businesses play the partnering role in the CSV cluster enablement. Conversely, our study shows the triggering effect that simulacra and visual representations could exert in SMEs to communicate, externally and to implement, internally, an integrated business approach to sustainability.

Concluding, even if our study might be affected by the neologism of "shared value", it shades light on the paramount importance of the need in improving sustainability and CSR's messages, disclosure, and of course practice. 


\section{Limitations and further developments}

Indeed, this study, is pioneering because of the application of methodologies which have not been consistently applied in accounting, reporting and accountability disciplines. It should be intended as a commentary on the uptrend concept of CSV and it's not free form limitations. For instance, as part of a pioneering approach, the number of sources for CSV-related disclosure collected has been limited, even because of the deductive nature of the study. Moreover, given the increasing role of visual imagery in corporate disclosure, we can assume that some stylistic choices are not imputable to simulacra effect, but graphical readability or trends. Furthermore, our findings should be tested according to other interpretative theory such as, for example, grounded theory that can lead to different results. Our study supports the importance of scientific enquire in the field of sustainability disclosure with focus on the lexical, terminological, and semantical role of the codes applied within the reporting practices. In fact, the overall trend of the incorrect use of terminological terms (that is the existence of cognitive synonyms one of each expressing a distinct concept) could effectively bring clearness to CSV stressing the differences between the concepts itself, with its applications over corporate's strategy and other overlapping theories and applications. Future researches might include the role of simulacra in the perceptions and comprehension of CSV in decision makers, that is, as reported by de los Reyes et al. (2016) one of the evolution of the CSV itself (between norm-taking vs. norm-making role).

\section{References}

Aakhus M, Bzdak M. 2012. Revisiting the Role of 'Shared Value' in the BusinessSociety Relationship. Business and Professional Ethics Journal 31: 231-246.

Aguinis H, Glavas A. 2012. What We Know and Don't Know About Corporate Social Responsibility: A Review and Research Agenda. Journal of Management 38: 932-968.

Babiak K, Trendafilova S. 2011. CSR and environmental responsibility: motives and pressures to adopt green management practices. Corporate Social Responsibility and Environmental Management 18: 11-24.

Baudrillard J. 1968. Le systeme des objets. Paris, Gallimard.

Baudrillard J. 1994. Simulacra and simulation. University of Michigan press.

Baumgartner RJ. 2014. Managing Corporate Sustainability and CSR: A Conceptual Framework Combining Values, Strategies and Instruments Contributing to Sustainable Development. Corporate Social Responsibility and Environmental Management 21: 258-271.

Beschorner T. 2013. Creating Shared Value: The One-Trick Pony Approach. Business Ethics Journal Review 1: 106-112.

Biswas A, Tortajada C, Biswas-Tortajada A, Joshi Y, Gupta A. 2014. Creating Shared Value. Impacts of Nestlé in Moga, India. Springer International Publishing.

Bockstette V, Stamp M. 2011. Creating Shared Value: A How-to Guide for the New 
Boesso G, Favotto F, Michelon G. 2015. Stakeholder Prioritization, Strategic Corporate Social Responsibility and Company Performance: Further Evidence. Corporate Social Responsibility and Environmental Management 22: 424-440.

Bosch-Badia MT, Montllor-Serrats J, Tarrazon MA. 2013. Corporate Social Responsibility from Friedman to Porter and Kramer. Theoretical Economics Letters 3: 11-15.

Burke L, Logsdon JM. 1996. How corporate social responsibility pays off. Long Range Planning 29: 495-502.

Carroll AB. 1999. Corporate Social Responsibility: Evolution of a Definitional Construct. Business \& Society 38: 268-295.

Chan CCC, Milne MJ. 1999. Investor reactions to corporate environmental saints and sinners: an experimental analysis. Accounting and Business Research 29: 265279.

Connelly BL, Certo ST, Ireland RD, Reutzel CR. 2011. Signaling Theory: A Review and Assessment. Journal of Management 37: 39-67.

Coy D, Pratt M. 1998. An insight into accountability and politics in universities: a case study. Accounting, Auditing \& Accountability Journal 11: 540-561.

Crane A, Palazzo G, Spence L, Matten D. 2014. Contesting the Value of 'Creating Shared Value'. California Management Review 56: 130-153.

de los Reyes G, Scholz M, Smith NC. 2016. Beyond the 'Win-Win': Creating Shared Value Requires Ethical Frameworks (No. Working Paper No. 2016/67/ATL/). California Management Review, Forthcoming.

Dembek K, Singh P, Bhakoo V. 2015. Literature Review of Shared Value: A Theoretical Concept or a Management Buzzword? Journal of Business Ethics 1 37.

Denning S. 2011. Why 'Shared Value' Can't Fix Capitalism. Forbes/Leadership.

Denning S. 2012. Is Shared Value a New Mental Model for Innovation? Forbes.

Donaldson T, Preston LE. 1995. The Stakeholder Theory of the Corporation: Concepts, Evidence, and Implications. Academy of Management Review 20: 6591.

Duran JJ, Bajo N. 2014. Institutions as Determinant Factors of Corporate Responsibility Strategies of Multinational Firms. Corporate Social Responsibility and Environmental Management 21: 301-317.

Economist. 2011. Oh, Mr Porter. The Economist - Schumpeter 2.

Elkington J. 1994. Towards the suitable corporation: win-win-win business strategies for sustainable development. California management review 36: 90-100.

Elkington J. 1997. Cannibals with forks. The triple bottom line of 21st century.

Elkington J. 2011. Don't abandon CSR for creating shared value just yet. The Guardian, 25th May.

Engert S, Rauter R, Baumgartner RJ. 2016. Exploring the integration of corporate sustainability into strategic management: A literature review. Journal of Cleaner Production.

Epstein J. M, Freedman M. 1994. Social Disclosure and the Individual Investor. Accounting, Auditing \& Accountability Journal 7: 94-109.

Firth M. 1979. The Impact of Size, Stock Market Listing, and Auditors on Voluntary Disclosure in Corporate Annual Reports. Accounting and Business Research 9: 273-280.

Freeman RE. 1984. Strategic Management: A Stakeholder Approach (Vol. 1). Boston: Pitman. 
Freeman RE, Wicks AC, Parmar B. 2004. Stakeholder Theory and 'The Corporate Objective Revisited'. Organization Science 15: 364-369.

Garriga E, Melé D. 2004. Corporate social responsibility theories: Mapping the territory. Journal of Business Ethics 53: 51-71.

Gonçalves MD de O. 2014. Microsoft BizSpark in Portugal: how to enhance entrepreneurship through the creation of shared value.

Gray R, Owen D, Adams C. 2009. Some theories for social accounting?: A review essay and a tentative pedagogic categorisation of theorisations around social accounting. Sustainability, Environmental Performance and Disclosures, Advances in Environmental Accounting \& Management (Vol. 4). CHAP Emerald Group Publishing Limited 1-54.

Gray R, Owen D, Adams C. 2009. Some theories for social accounting?: A review essay and a tentative pedagogic categorisation of theorisations around social accounting. Sustainability, Environmental Performance and Disclosures, Advances in Environmental Accounting \& Management (Vol. 4). Emerald Group Publishing Limited 1-54.

Gray S, Chan A, Clark D, Jordan R. 2012. Modeling the integration of stakeholder knowledge in social-ecological decision-making: Benefits and limitations to knowledge diversity. Ecological Modelling 229: 88-96.

Gray S, Gray S, Cox L, Henly-Shepard S. 2013. Mental modeler: A fuzzy-logic cognitive mapping modeling tool for adaptive environmental management. Proceedings of the 46th International Conference on Complex Systems 963-973.

Harrison JS, Wicks AC. 2013. Stakeholder Theory, Value, and Firm Performance. Business Ethics Quarterly 23: 97-124.

Hart SL. 1995. A Natural-Resource-Based View of the Firm. Academy of Management Review 4: 986-1014.

Hartman LP, Werhane PH. 2013. Proposition: Shared Value as an Incomplete Mental Model. Business Ethics Journal Review 1: 36-43.

IAOA. 2015. The International Association for Ontology and its Applications.

Idemudia U, Ite UE. 2006. Corporate-community relations in Nigeria's oil industry: challenges and imperatives. Corporate Social Responsibility and Environmental Management 13: 194-206.

Jenkins H. 2004. Corporate social responsibility and the mining industry: conflicts and constructs. Corporate Social Responsibility and Environmental Management 11: $23-34$.

Jensen MC. 2002. Value Maximization, Stakeholder Theory, and the Corporate Objective Function. Business Ethics Quarterly 12: 235-256.

Juscius V, Jonikas D. 2013. Integration of CSR into Value Creation Chain: Conceptual Framework. Engineering Economics 24: 63-70.

Kitzmueller M, Shimshack J. 2012. Economic Perspectives on Corporate Social Responsibility. Journal of Economic Literature 50: 51-84.

Klein J, Dawar N. 2004. Corporate social responsibility and consumers' attributions and brand evaluations in a product-harm crisis. International Journal of Research in Marketing 21: 203-217.

Kolodinsky RW, Bierly PE. 2013. Understanding the elements and outcomes of executive wisdom: A strategic approach. Journal of Management and Organization 19: 1-24.

Kosko B. 1986. Fuzzy cognitive maps. International Journal of Man-Machine Studies 24: $65-75$.

Kramer MR, Pfitzer MW. 2016. The Ecosystem of Shared Value. Harvard Business 
Larsson A, Buhr K, Mark-Herbert C. 2013. Corporate responsibility in the garment industry: Towards shared value. Sustainability in Fashion and Textiles : Values, Design, Production and Consumption. Greenleaf Publishing Ltd 262-276.

Lee DP. 2005. Social and environmental accountability research. Accounting, Auditing \& Accountability Journal 18: 842-860.

Lindgreen A, Swaen V. 2010. Corporate Social Responsibility. International Journal of Management Reviews 12: 1-7.

Lockett A, Moon J, Visser W. 2006. Corporate Social Responsibility in Management Research: Focus, Nature, Salience and Sources of Influence*. Journal of Management Studies 43: 115-136.

Lozano R. 2015. A Holistic Perspective on Corporate Sustainability Drivers. Corporate Social Responsibility and Environmental Management 22: 32-44.

Lund-Thomsen P, Nadvi K. 2010. Global value chains, local collective action and corporate social responsibility: a review of empirical evidence. Business Strategy and the Environment 19: 1-13.

Macintosh NB, Shearer T, Thornton DB, Welker M. 2000. Accounting as simulacrum and hyperreality: perspectives on income and capital. Accounting, Organizations and Society 25: 13-50.

Maltz E, Thompson F, Ringold DJ. 2011. Assessing and maximizing corporate social initiatives: a strategic view of corporate social responsibility. Journal of Public Affairs (14723891) 11: 344-352.

Marti CP, Rovira-Val MR, Drescher LGJ. 2015. Are Firms that Contribute to Sustainable Development Better Financially? Corporate Social Responsibility and Environmental Management 22: 305-319. JOUR.

Mattesich R. 2000. The beginnings of accounting and accounting thought. Accounting Practice in the Middle East (8000 BC to 2000 BC) and Accounting Thought in India (300 BC and the Middle Ages). London: Routledge.

McWilliams A, Parhankangas A, Coupet J, Welch E, Barnum DT. 2016. Strategic Decision Making for the Triple Bottom Line. Business Strategy and the Environment 25: 193-204.

McWilliams A, Van Fleet DD, Cory KD. 2002. Raising Rivals' Costs Through Political Strategy: An Extension of Resource-based Theory. Journal of Management Studies 39: 707-724.

Michelon G, Boesso G, Kumar K. 2013. Examining the Link between Strategic Corporate Social Responsibility and Company Performance: An Analysis of the Best Corporate Citizens. Corporate Social Responsibility and Environmental Management 20: 81-94.

Milne MJ, Chan CCC. 1999. Narrative corporate social disclosures: how much of a difference do they make to investment decision-making? The British Accounting Review 31: 439-457.

Moon H-C, Pare J, Yim SH, Park N. 2011. An Extension of Porter and Kramer's Creating Shared Value (CSV): Reorienting Strategies and Seeking International Cooperation. Journal of International and Area Studies 18: 49-64. JOUR.

Murray R, Caulier-Grice J, Mulgn G. 2010. The Open Book of Social Innovation. London: National endowment for science, technology and the art.

Neu D, Warsame H, Pedwell K. 1998. Managing Public Impressions: Environmental Disclosures in Annual Reports. Accounting, Organizations and Society 23: 265282.

Neugebauer F, Figge F, Hahn T. 2016. Planned or Emergent Strategy Making? 
Exploring the Formation of Corporate Sustainability Strategies. Business Strategy and the Environment 25: 323-336.

Norese MF, Salassa F. 2014. Structuring fragmented knowledge: a case study. Knowledge Management Research \& Practice 12: 454-463.

Panapanaan V, Bruce T, Virkki-Hatakka T, Linnanen L. 2016. Analysis of Shared and Sustainable Value Creation of Companies Providing Energy Solutions at the Base of the Pyramid (BoP). Business Strategy and the Environment 25: 293-309.

Pätäri S, Arminen H, Tuppura A, Jantunen A. 2014. Competitive and Responsible? The Relationship between Corporate Social and Financial Performance in the Energy Sector. Renewable and Sustainable Energy Reviews 37: 142-154.

Patari S, Jantunen A, Kylaheiko K, Sandstrom J. 2012. Does Sustainable Development Foster Value Creation? Empirical Evidence from the Global Energy Industry. Corporate Social Responsibility and Environmental Management 19: 317-326.

Pavlovich K, Corner P. 2014. Conscious Enterprise Emergence: Shared Value Creation Through Expanded Conscious Awareness. Journal of Business Ethics 121: 341-351.

Porter M, Hills G, Pfitzer M, Patscheke S, Hawkins E. 2012. Measuring shared value: How to unlock value by linking social and business results. Conference Report available ... 1-24.

Porter ME. 1979. How Competitive Forces Shape Strategy. Harvard business Review 137-145.

Porter ME. 1980. Competitive Strategy. New York: Free Press (Vol. 1).

Porter ME. 1985. Competitive Advantage:Creating and sustaining superior performance (Vol. 15). New York: The Free Press.

Porter ME, Kramer MR. 2006. The link between competitive advantage and corporate social responsibility. Harvard Business Review 84: 78-92.

Porter ME, Kramer MR. 2011. The Big Idea : Creating Shared Value. Harvard Business Review 89: 1-2.

Quattrone P. 2009. Books to be practiced: Memory, the power of the visual, and the success of accounting. Accounting, Organizations and Society 34: 85-118.

Rocchi M, Ferrero I. 2014. Systematic Shared Value in Finance: Expanding Porter's Approach. Universitad de Navarra Working Pa: 1-31.

Schmitt J. 2014. Social Innovation for Business Success: Shared Value in the Apparel Industry. Springer Science \& Business Media.

Schmitz J, Schrader J. 2015. Corporate Social Responsibility: A Microeconomic Review of The Literature. Journal of Economic Surveys 29: 27-45.

Smith A. 1759. The theory of moral sentiments. (Macfie AL \& Raphael D., Eds.). Oxford: Oxford University Press.

Spence LJ. 2014. Small Business Social Responsibility: Expanding Core CSR Theory. Business \& Society 0007650314523256-.

Spence M. 2002. Signaling in retrospect and the informational structure of markets. American Economic Review 434-459.

Spitzeck H, Chapman S. 2012. Creating shared value as a differentiation strategy-the example of BASF in Brazil. Corporate Governance 12: 499-513.

Szmigin I, Rutherford R. 2013. Shared Value and the Impartial Spectator Test. Journal of Business Ethics 114: 171-182.

Unerman J. 2000. Methodological issues $\square$ Reflections on quantification in corporate social reporting content analysis. Accounting, Auditing \& Accountability Journal 13: $667-681$. 
Ware C. 2013. Information Visualization. Waltham, USA: Elsevier.

Weber RP. 1990. Basic content analysis. Beverly Hills: SAGE.

Werther WB, Chandler D. 2005. Strategic corporate social responsibility as global brand insurance. Business Horizons 48: 317-324.

Wilburn K, Wilburn R. 2014. Demonstrating a Commitment to Corporate Social Responsibility Not Simply Shared Value. Business and Professional Ethics Journal 33: 1-15. 
Table 1 -Sample composition.

\begin{tabular}{|c|c|c|c|c|}
\hline Organisation & Industry & Headquarters & Size & $\begin{array}{l}\text { Database } \\
\text { selection }\end{array}$ \\
\hline Arauco & Agriculture & Chile & $\mathrm{MNC}$ & SVI \\
\hline Avista & Energy & USA & Local & GRI \\
\hline $\mathrm{BD}$ & Medical & USA & $\mathrm{MNC}$ & SVI \\
\hline $\begin{array}{l}\text { British American } \\
\text { Tobacco }\end{array}$ & Tobacco & UK & $\mathrm{MNC}$ & GRI \\
\hline BT Group & Telecommunication & UK & $\mathrm{MNC}$ & SVI \\
\hline Coca Cola & Beverage & USA & $\mathrm{MNC}$ & SVI \\
\hline $\begin{array}{l}\text { Development Bank of } \\
\text { Singapore }\end{array}$ & Financial Services & Singapore & $\mathrm{MNC}$ & IIRC \\
\hline Entergy & Energy & USA & Local & GRI \\
\hline Exxaro Resources & Minerals & South Africa & Local & IIRC \\
\hline FarmHub & Agriculture & USA & International & $\begin{array}{l}\text { Porter and } \\
\text { Kramer } \\
\text { explicit } \\
\text { reference }\end{array}$ \\
\hline Fuji/Xerox & Electronics & Japan & $\mathrm{MNC}$ & SVI \\
\hline Hess Corporation & Chemicals & USA & $\mathrm{MNC}$ & SVI \\
\hline Intel & Electronics & USA & $\mathrm{MNC}$ & SVI \\
\hline InterContinental Hotels & Hospitality & UK & $\mathrm{MNC}$ & SVI \\
\hline Itau Unibanco & Financial Services & Brazil & $\mathrm{MNC}$ & SVI \\
\hline Kirin Group & $\begin{array}{l}\text { Beverage \& } \\
\text { Pharmaceutical }\end{array}$ & Japan & $\mathrm{MNC}$ & SVI \\
\hline Lilly & Pharmaceutical & USA & $\mathrm{MNC}$ & SVI \\
\hline Nestlé & Food & Switzerland & $\mathrm{MNC}$ & SVI \\
\hline New Zealand Post & Postal Services & New Zealand & Local & SVI \\
\hline Oil Search & Energy & Papua New Guinea & $\mathrm{MNC}$ & GRI \\
\hline Pacific Rubiales Energy & Energy & Canada & $\mathrm{MNC}$ & SVI \\
\hline RoyalDSM & Chemical & Benelux & $\mathrm{MNC}$ & SVI \\
\hline S.T. Corporation & Cleaning & Japan & Local & IIRC \\
\hline Samsung & Electronics & South Korea & $\mathrm{MNC}$ & SVI \\
\hline Schneider Electric & Electronics & France & $\mathrm{MNC}$ & SVI \\
\hline Seven Energy & Energy & Nigeria/UK & Local & GRI \\
\hline SNAM & Utilities & Italy & $\mathrm{MNC}$ & GRI \\
\hline Volvo & Automotive & Sweden & $\mathrm{MNC}$ & GRI \\
\hline Western Union & Financial Services/TLC & USA & $\mathrm{MNC}$ & SVI \\
\hline
\end{tabular}


Table 2 - Composition of the signals: channels, type of signals and extract of the textual signals analysed 


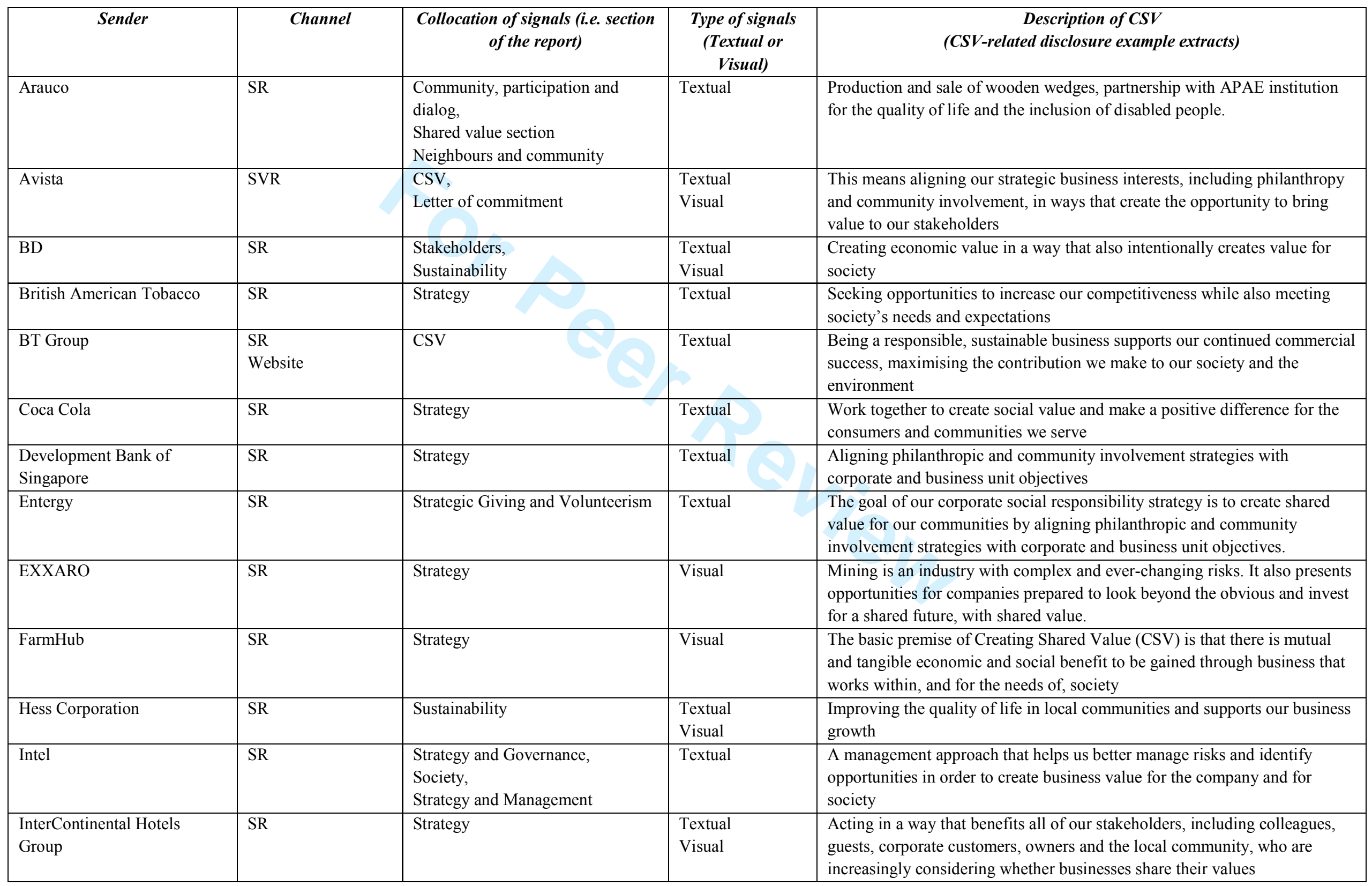




\begin{tabular}{|c|c|c|c|c|}
\hline Itau Unibanco & SR & Strategy/Relationships & $\begin{array}{l}\text { Textual } \\
\text { Visual }\end{array}$ & $\begin{array}{l}\text { Providing knowledge and suitable financial solutions, which helps } \\
\text { companies and individuals develop a healthy relationship with money }\end{array}$ \\
\hline Kirin Group & AR & Strategy & $\begin{array}{l}\text { Textual } \\
\text { Visual }\end{array}$ & $\begin{array}{l}\text { Combine engagement in societal issues to create social value with } \\
\text { improvement of a company's competitive position }\end{array}$ \\
\hline Lilly & SR & Strategy & Textual & $\begin{array}{l}\text { Creation of sustainable, profitable business solutions at the intersection of } \\
\text { societal needs, business expertise, and business opportunity }\end{array}$ \\
\hline Nestlè & SR & CSV & Visual & $\begin{array}{l}\text { We see this value creation as a basic requirement for successful business, but } \\
\text { it doesn't stop there. Being a global leader brings not only a duty to operate } \\
\text { responsibly, but also an opportunity to create long-term positive value for } \\
\text { society. We call this Creating Shared Value, and we embed it firmly in our } \\
\text { holistic management thinking across all parts of our business }\end{array}$ \\
\hline New Zealand Post & AR & 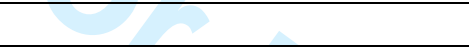 & Textual & Support community social enterprise development \\
\hline Oil Search & SR & Sustainability strategy & $\begin{array}{l}\text { Textual } \\
\text { Visual }\end{array}$ & $\begin{array}{l}\text { By creating opportunities which benefit the community and contribute to the } \\
\text { continuity of our operations }\end{array}$ \\
\hline Pacific Rubiales Energy & SR & Strategy & Textual & $\begin{array}{l}\text { Corporate policies and practices that enhance the competitiveness of our } \\
\text { Company and simultaneously social and economic conditions of the } \\
\text { communities where we operate }\end{array}$ \\
\hline Royal DSM & AR & $\begin{array}{l}\text { Presentation } \\
\text { Stakeholder engagement }\end{array}$ & $\begin{array}{l}\text { Textual } \\
\text { Visual }\end{array}$ & $\begin{array}{l}\text { Innovating in ways that allow its customers to provide better People, Planet } \\
\text { and Profit solutions - solutions to the challenges facing society, the } \\
\text { environment and end-users. }\end{array}$ \\
\hline S.T. Corporation & SR & Sustainability/Strategy & Textual & $\begin{array}{l}\text { CSR initiatives that entail leveraging its strengths in revolutionizing sundry } \\
\text { items to create shared value with all its current and future stakeholders in a } \\
\text { manner that addresses social and environmental issues }\end{array}$ \\
\hline Samsung & SR & $\begin{array}{l}\text { CSV, Global Code of Conduct, } \\
\text { Social Contribution, Customer care }\end{array}$ & $\begin{array}{l}\text { Textual } \\
\text { Visual }\end{array}$ & Create new value through eco-innovation \\
\hline Schneider Electric & SR & Company Overview & Textual & $\begin{array}{l}\text { By making sustainability a priority in everything we do, we are able to } \\
\text { achieve continuous improvement } \\
\text { in our performance while delivering a fair revenue breakdown }\end{array}$ \\
\hline Seven Energy & SR & CSR & Textual & $\begin{array}{l}\text { Deliver value and improved standards of living to Nigerians through our } \\
\text { integrated business model to supply gas to the Nigerian domestic market }\end{array}$ \\
\hline SNAM & AR SR & $\begin{array}{l}\text { Sustainability/Stakeholders } \\
\text { Shared value section } \\
\text { Toward the creation of shared } \\
\text { value }\end{array}$ & $\begin{array}{l}\text { Textual } \\
\text { Visual }\end{array}$ & $\begin{array}{l}\text { Aligning the company's vision concerning value created for itself and its } \\
\text { stakeholders }\end{array}$ \\
\hline Volvo & SR & Strategy & $\begin{array}{l}\text { Textual } \\
\text { Visual }\end{array}$ & $\begin{array}{l}\text { Development of practices that enhance our competitiveness while } \\
\text { simultaneously advancing the economic, environmental and social } \\
\text { conditions of the societies in which the Group operate }\end{array}$ \\
\hline Western Union & AR SR & $\begin{array}{l}\text { Presentation of the firm } \\
\text { CSV }\end{array}$ & $\begin{array}{l}\text { Textual } \\
\text { Visual }\end{array}$ & $\begin{array}{l}\text { We're helping to foster more self-sufficient local economies and enabling } \\
\text { people to grow }\end{array}$ \\
\hline
\end{tabular}

http://mc.manuscriptcentral.com/csrem 
Table 3 - Frequencies of the reference to "shared value" within the analysed channels.

\begin{tabular}{|c|c|c|c|c|c|c|c|c|}
\hline & \multicolumn{8}{|c|}{ Citations by reporting periods } \\
\hline & 2010 & 2011 & 2012 & 2013 & 2014 & First edition & Second edition & Third edition \\
\hline Arauco & & 3 & 11 & 11 & & 3 & 11 & 11 \\
\hline Avista & & 19 & 26 & 18 & 24 & 19 & 26 & 18 \\
\hline $\mathrm{BD}$ & & 3 & 11 & 6 & & 3 & 11 & 6 \\
\hline British American Tobacco & & 5 & 2 & 6 & & 5 & 2 & 6 \\
\hline BT Group & & & & & 5 & & & \\
\hline Coca Cola & & & & & 1 & & & \\
\hline Development Bank of Singapore & & & & 2 & & & & \\
\hline Entergy & & 1 & 4 & 1 & & 1 & 4 & 1 \\
\hline Hess Corporation & & & & 3 & & & & \\
\hline Intel & 4 & 2 & 11 & 12 & & 2 & 11 & 12 \\
\hline InterContinental Hotels Group & & & 7 & 18 & 6 & 7 & 18 & 6 \\
\hline Itau Unibanco & $\bar{T}$ & 13 & 7 & 8 & & 13 & 7 & 8 \\
\hline Kirin Group & & & 5 & 6 & & 5 & 6 & \\
\hline Lilly & & & & 5 & & & & \\
\hline New Zealand Post & & & & 1 & & & & \\
\hline Oil Search & & & 12 & 14 & & 12 & 14 & \\
\hline Pacific Rubiales Energy & & & 10 & & & & & \\
\hline RoyalDSM & & 8 & 10 & 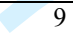 & & 8 & 10 & 9 \\
\hline S.t. Corporation & & & 1 & 4 & & & & \\
\hline Samsung & 2 & 0 & 1 & 7 & 3 & 1 & 7 & 3 \\
\hline Schneider Electric & & & 4 & 3 & 3 & 4 & 3 & 3 \\
\hline Seven Energy & & & 1 & 1 & & 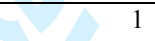 & 1 & \\
\hline SNAM & & 19 & 18 & 23 & & 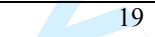 & 18 & 23 \\
\hline Volvo & & 13 & 4 & 25 & & 13 & 4 & 25 \\
\hline Western Union & & & & 23 & & & & \\
\hline Total & 6 & 86 & 145 & 206 & 42 & & & \\
\hline
\end{tabular}


Table 4-Clustering of CSV visual signals according to the grammar of information visualization.

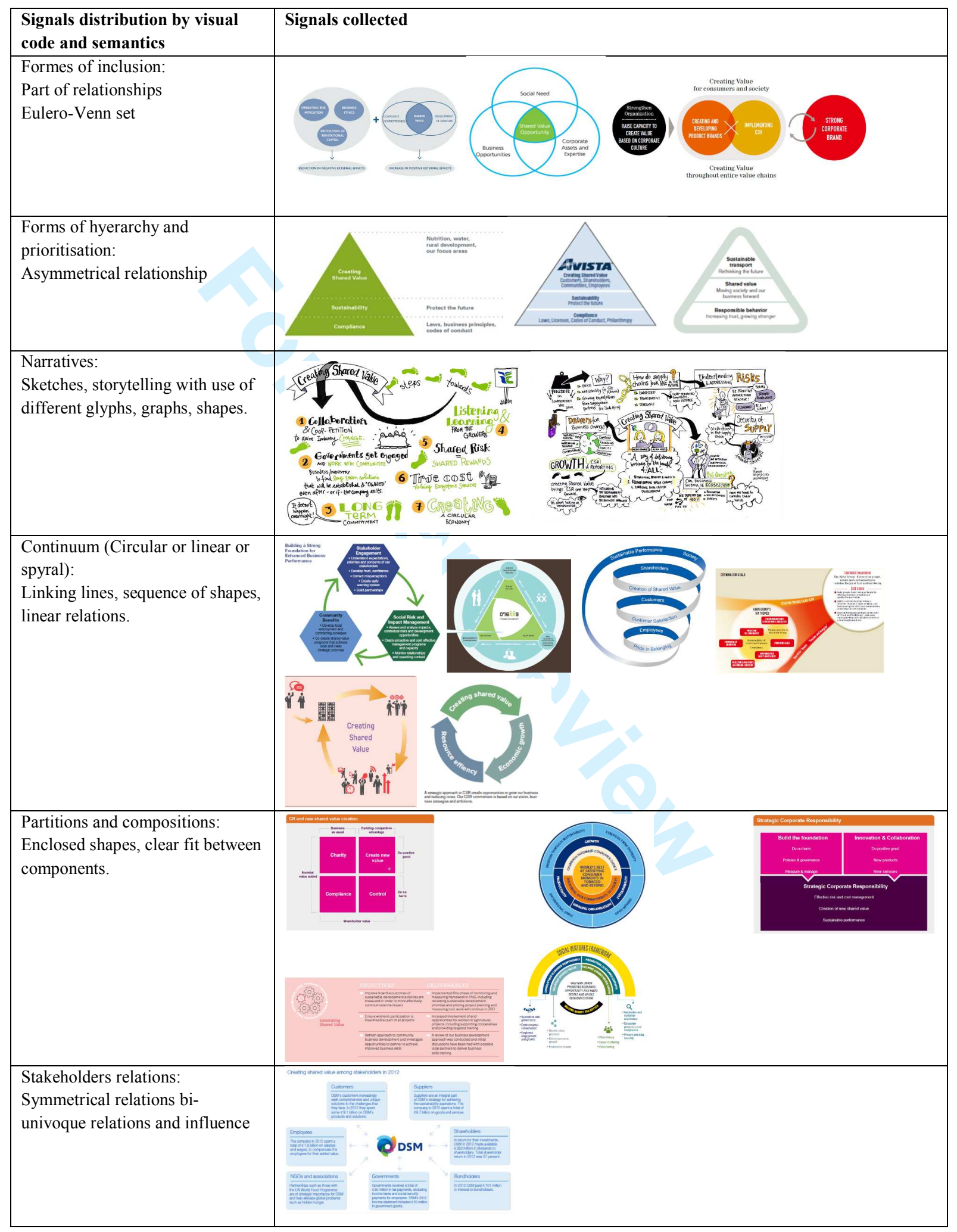


Figure 1 Outline of the sample selection process and related outcomes [INSERT FIGURE 1 HERE]

$13 \times 6 \mathrm{~mm}(600 \times 600 \mathrm{DPI})$ 


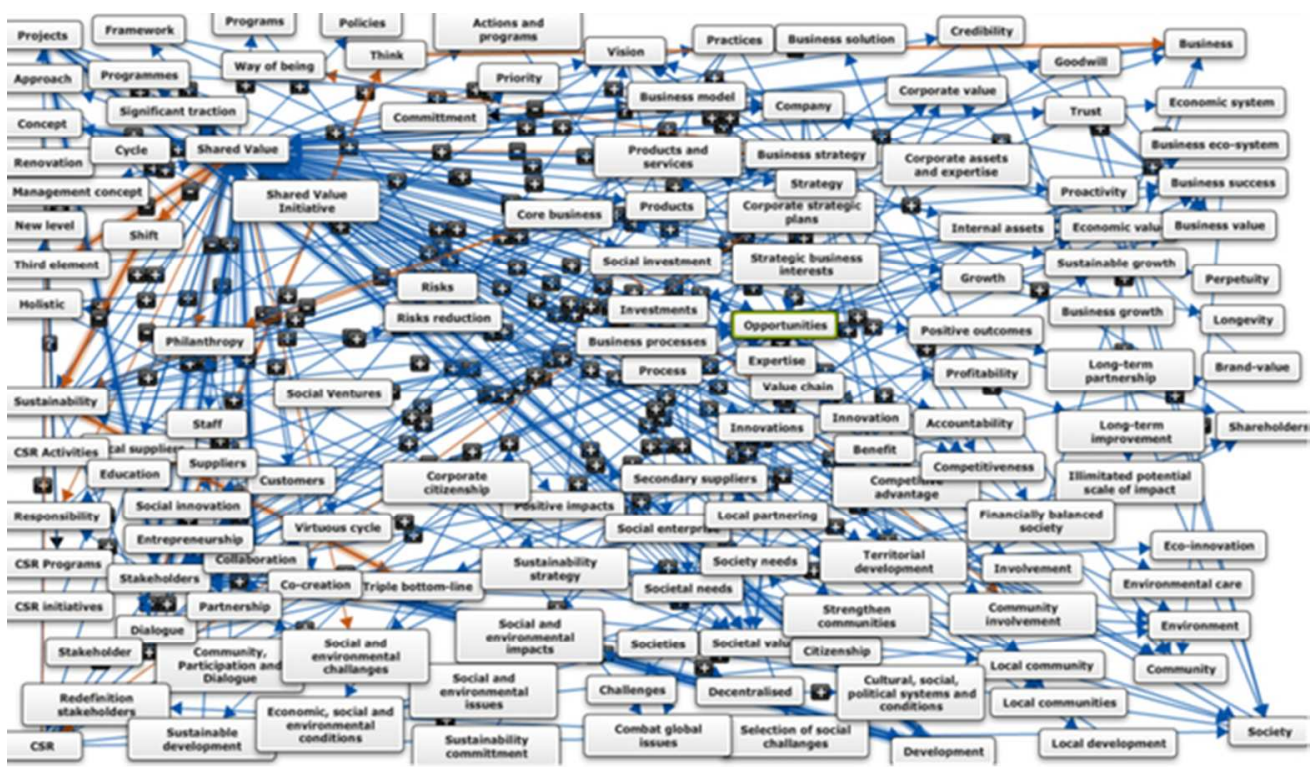

Figure 2 Global Cognitive Maps on CSV [INSERT FIGURE 2 HERE] $27 \times 16 \mathrm{~mm}(600 \times 600 \mathrm{DPI})$ 


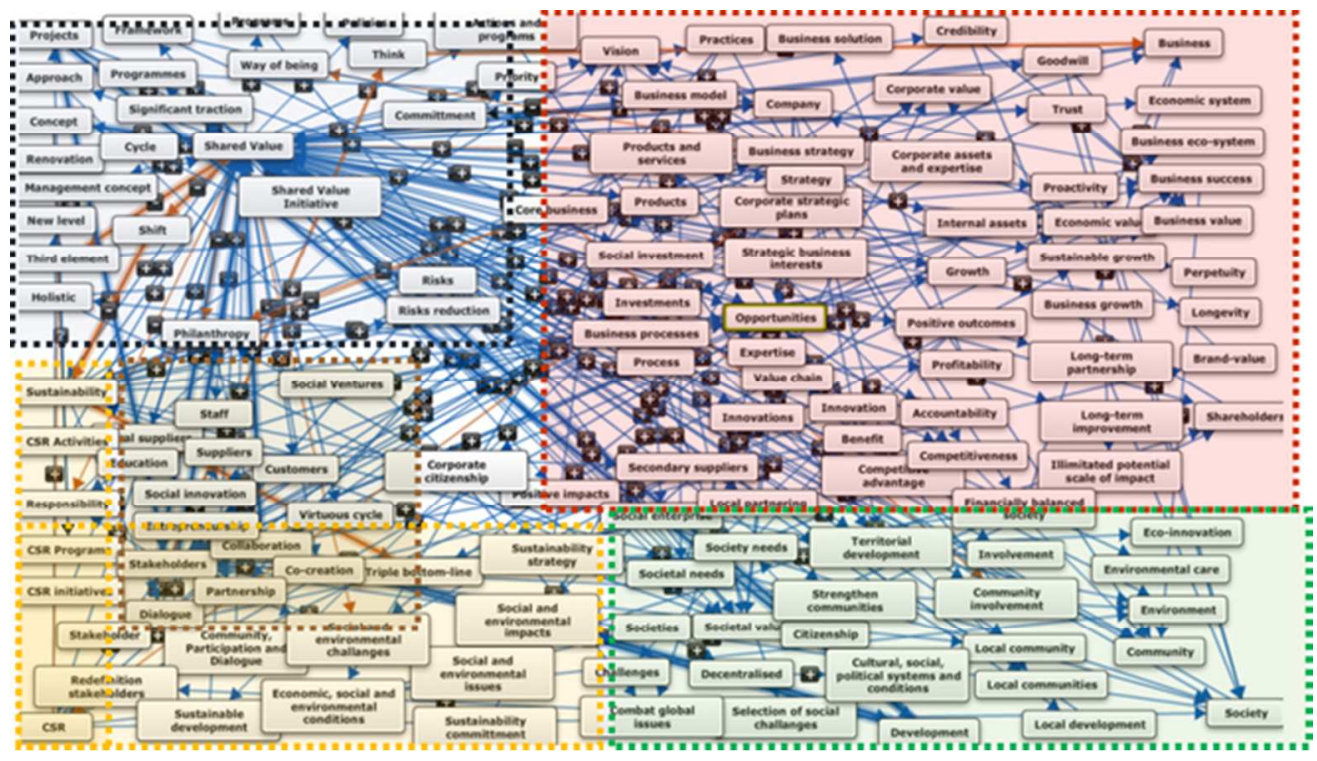

Figure 3 Clustered Cognitive Map [INSERT FIGURE 3 HERE] $27 \times 15 \mathrm{~mm}(600 \times 600 \mathrm{DPI})$ 


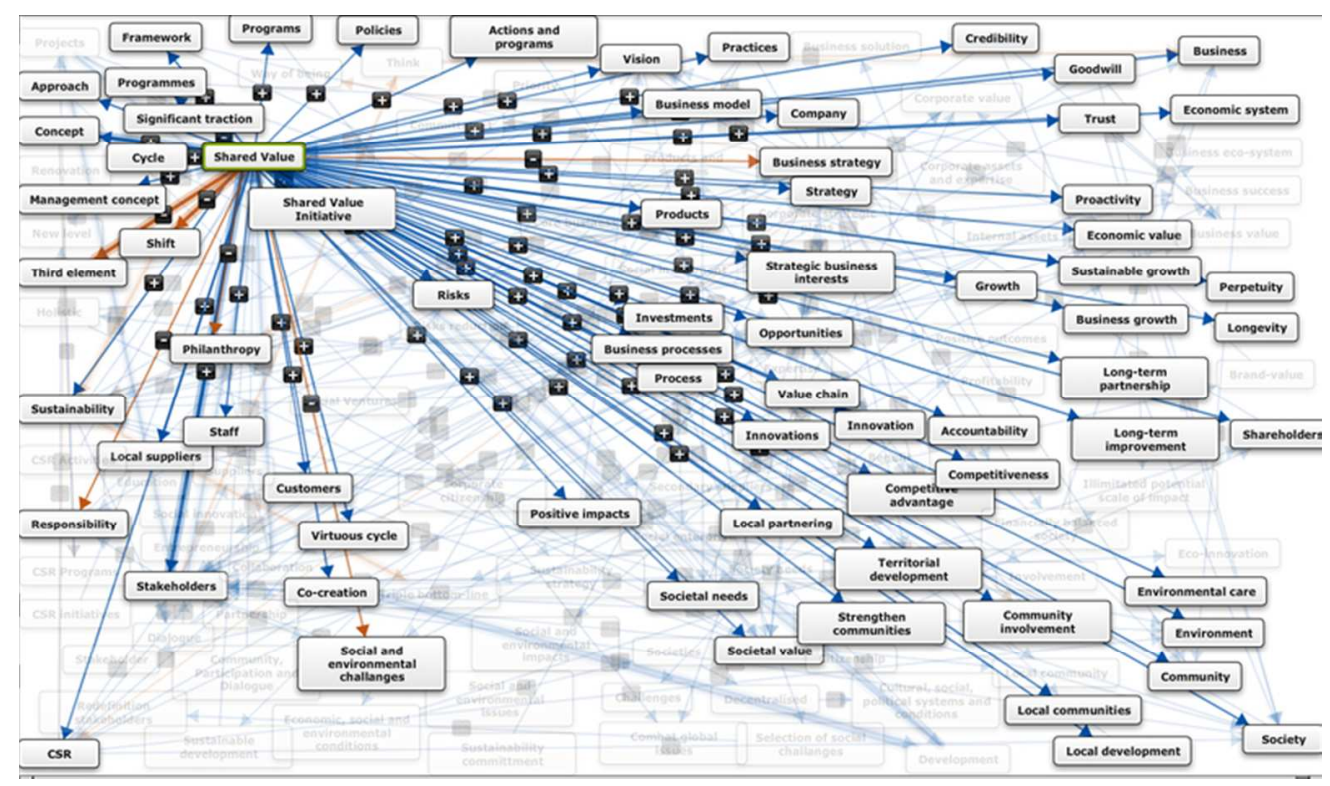

Figure 4 Influence from CSV [INSERT FIGURE 4 HERE] $33 \times 19 \mathrm{~mm}(600 \times 600 \mathrm{DPI})$ 


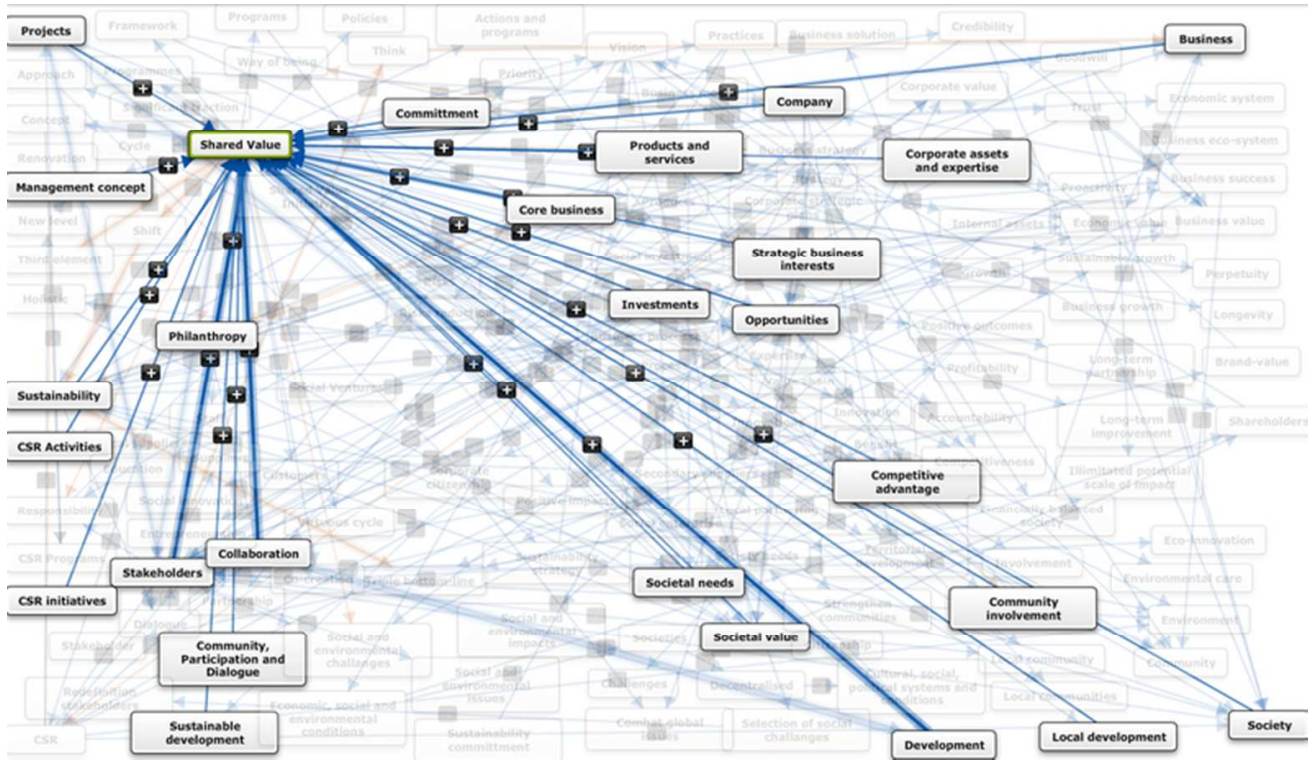

Figure 5 Influence on CSV [INSERT FIGURE 5 HERE] $33 \times 19 \mathrm{~mm}(600 \times 600 \mathrm{DPI})$ 
6.9

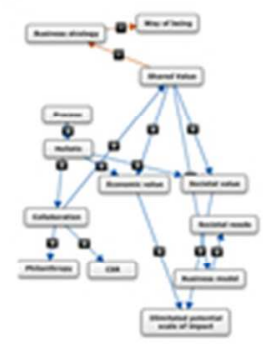

Figure 6 Examples of non-cause-effect relationship [INSERT FIGURE 6 HERE] $13 \times 7 \mathrm{~mm}(600 \times 600 \mathrm{DPI})$ 


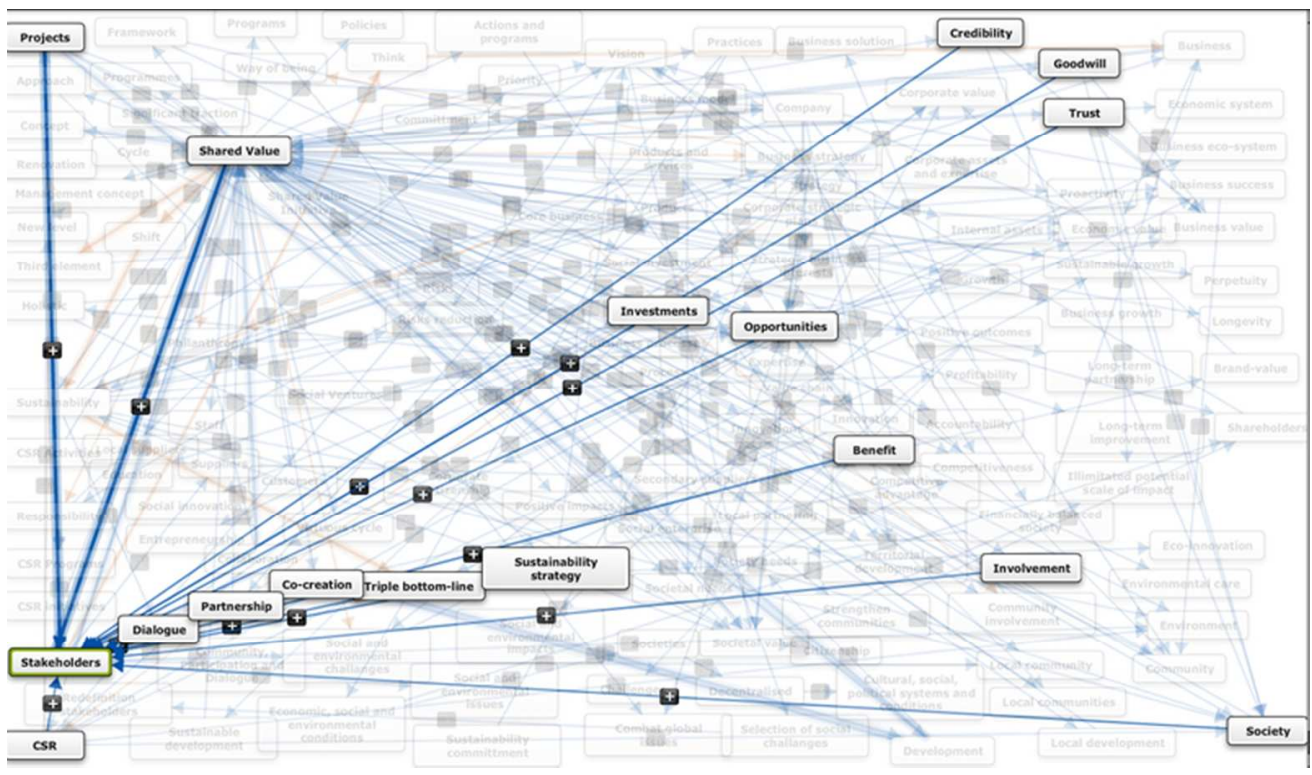

Figure 7 Relation between CSV and stakeholders [INSERT FIGURE 7 HERE]

$33 \times 19 \mathrm{~mm}(600 \times 600 \mathrm{DPI})$ 


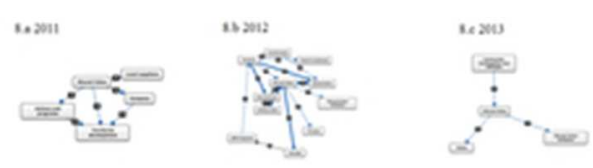

Figure 8 Trend in complexity and its reduction over time (example of a single organization) [INSERT FIGURE 8 HERE]

$10 \times 2 \mathrm{~mm}(600 \times 600 \mathrm{DPI})$ 